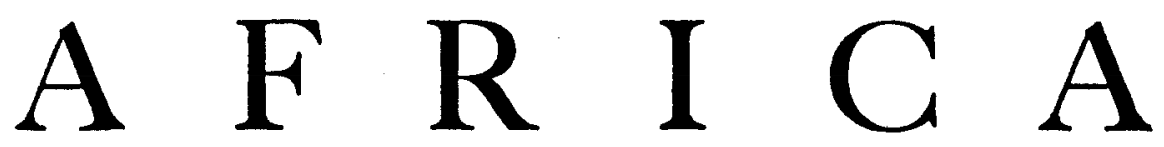

JOURNAL OF THE INTERNATIONAL AFRICAN INSTITUTE

\title{
OBITUARY
}

\section{FRANS OLBRECHTS}

$A^{S}$ announced briefly in the April number of Africa we heard with the deepest A regret the news of the death on 24 March of Professor Frans Olbrechts, Director of the Musée Royal du Congo Belge, Consultative Director and Member of the Executive Council of the Institute.

Frans Maria S. Olbrechts was born at Malines on 16 February I 899 . He read philology at the University of Louvain and then went to the United States to study anthropology under Professor Franz Boas at Columbia University. During his stay in the United States he did field-work among the Cherokee Indians, of whose religion he made a special study, and he collaborated with J. Mooney in editing The Swimmer Manuscript for publication.

On his return to Belgium in I929, Frans Olbrechts was entrusted with the organization of the Department of Ethnology at the Musées Royaux d'Art et d'Histoire in Brussels. In 1932 he became a professor at the University of Ghent, giving courses on ethnology, museum craft, and especially on primitive art, for the study of African plastic art became his main interest and he attained an unrivalled knowledge of the collections from all parts of Africa. The fruits of his intensive study of the wealth of material from the Belgian Congo available in collections in Belgium and elsewhere were published in Plastiek van Kongo, 1946, in which he distinguished and analysed with consummate skill a number of distinct stylistic traditions that had developed in different parts of Central Africa. He had, before his death, completed most of the work for a revised French edition of this study and its publication will be eagerly awaited. His ethnographic expeditions to French West Africa were also mainly directed to the collection of material on African art and the results were published in his studies Het rode Land der zwarte Kariatiden, 1935, and Maskers en Dansers in de Ivoorkust, 1940.

In 1947 Professor Olbrechts became Director of the Musée du Congo Belge at Tervuren, a position from which he was able not only to extend and reorganize the museum's collections and to make them more widely known, but also to serve on many Belgian and international bodies concerned with African research. He took a leading part in the organization of the Brussels meeting of the International Congress of Anthropological and Ethnological Sciences in 1948, and was a member of the

'Africa', the Journal of the International African Institute, is published by the Institute, but except where otherwise stated the writers of the articles are responsible for the opinions expressed. 
Executive Committee of the Institut de Recherche Scientifique en Afrique Centrale, established by the Belgian authorities to develop scientific research in the Congo after the war. As the Chairman of its Human Sciences Commission he played a leading part in the development of field research in social anthropology in the Belgian Congo and in the establishment of its anthropological research centre at Astrida in Ruanda. Professor Olbrechts also presided over the special conference convened by CCTA in collaboration with the Belgian Congo authorities, which met at Bukavu in I95s to review progress and frame proposals for further developments in the human sciences in Africa.

Professor Olbrechts was first elected a member of the Executive Council of the International African Institute in 1947 and in 1950 succeeded the late Professor Édouard de Jonghe as a Consultative Director. Both at the meetings of its Council and committees and in personal relations with those concerned with the work of the Institute, the enthusiasm and unfailingly constructive and co-operative spirit of Frans Olbrechts were greatly valued. His kindliness, wide range of interests, and his readiness to assist in all aspects of the Institute's work, and to extend its activities in Belgium and the Belgian Congo, won him the friendship and respect of members from many countries. The severe illness from which he suffered greatly over the past two years was borne with splendid courage. Members of the Institute will share the grief of their Belgian colleagues in the loss of so distinguished and lovable an Africanist, and wish to assure Madame Olbrechts and the Musée Royal du Congo Belge of their appreciation of the great services he rendered.

DARYLL Forde 